\title{
Effects of isolation and environmental variables on fish community structure in the Brazilian Amazon Madeira-Purus interfluve
}

\author{
Barros, DF. ${ }^{a}$, Albernaz, ALM. ${ }^{a}$, Zuanon, $J^{b}$, Espírito Santo, $H M V^{c}$, , \\ Mendonça, FP. ${ }^{d}$ and Galuch, $A V^{b}$ \\ ${ }^{a}$ Coordenação de Ciências da Terra e Ecologia, Museu Paraense Emílio Goeldi, Av. Perimetral 1901, CEP 66077-830, \\ Belém, PA, Brazil \\ ${ }^{b}$ Coordenação de Pesquisas em Biodiversidade, Instituto Nacional de Pesquisas da Amazônia, Avenida André Araújo \\ 2936, CP 478, CEP 69011-970, Manaus, AM, Brazil \\ ${ }^{c}$ Coordenação de Pesquisas em Ecologia, Instituto Nacional de Pesquisas da Amazônia, Avenida André Araújo 2936, \\ Aleixo, CP 478, CEP 69060-001, Manaus, AM, Brazil \\ ${ }^{d}$ Instituto de Saúde e Biotecnologia, Universidade Federal do Amazonas, Rua Coari-Mamiá 305, Espírito Santo, \\ CEP 69460-000, Coari, AM, Brazil \\ *e-mail:dani_fbarros@yahoo.com.br.
}

Received April 23, 2012 - Accepted August 29, 2012 - Distributed August 31, 2013

(With 3 figures)

\begin{abstract}
Due to the existence of terrestrial barriers to freshwater fish dispersion, it is believed that its distribution is strongly associated with historical factors related to the formation of the habitats they occupy. By the other hand, some studies reveal the influence of abiotic conditions (such as size of water bodies, $\mathrm{pH}$, conductivity) on the composition of fish fauna occurring in small streams. This study aimed to investigate whether drainage basins, because catchment boundaries are potential barriers to fish dispersion, or the physical structure and physico-chemical characteristics of water have a greater influence on fish community structure in small streams. We sampled 22 streams belonging to five drainage basins in the Madeira-Purus interfluve. Fish were caught with dip nets and a small trawl, and data were simultaneously obtained on structural characteristics of the streams and physico-chemical characteristics of the water. Community composition was analyzed using Non-Metric Multidimensional Scaling (NMDS), and variables related to structural and physico-chemical characteristics were summarized by Principal Component Analysis (PCA). Two explanatory models relating faunal composition to environmental factors were constructed: the first using only continuous variables and the second including the drainage basin as a categorical variable. The Akaike Information Criterion (AIC) and AIC weight were used to select the best model. Although structural and physico-chemical variables significantly contributed to explaining faunal composition, the model including the drainage basin was clearly the better of the two models (more than $90 \%$ support in the data). The importance of drainage basins in structuring fish communities in streams may have significant consequences for conservation planning in these environments.
\end{abstract}

Keywords: Ichthyofauna, fish ecology, physical variables, chemical variables, western Amazon.

\section{Efeito do isolamento e das variáveis ambientais na estrutura de comunidades de peixes do interflúvio Madeira-Purus na Amazônia brasileira}

\section{Resumo}

Devido à existência de barreiras terrestres à dispersão de peixes de água doce, acredita-se que sua distribuição é fortemente associada a fatores históricos relacionados à formação dos habitats que ocupam. Por outro lado, alguns estudos revelam a influência de condições abióticas (tais como o tamanho do corpo d'água, pH, condutividade) na composição da fauna ictiíca de rios de pequena ordem. Este trabalho teve como objetivo investigar se bacias hidrográficas, cujo divisor de águas representa uma potencial barreira para a dispersão dos peixes, ou a estrutura física e características físico-químicas da água têm maior efeito sobre a estrutura de comunidades de peixes de riachos de pequena ordem. Foram amostrados 22 riachos, pertencentes a cinco bacias hidrográficas no interflúvio Madeira-Purus. Os peixes foram capturados com puçás e uma pequena rede de arrasto, e simultaneamente foram obtidos dados sobre as características estruturais dos riachos e físico-químicas da água. A composição das comunidades foi analisada por meio de um Escalonamento Multidimensional Não-Métrico (NMDS) e as variáveis relacionadas às características estruturais e físico-químicas foram sintetizadas por meio de uma Análise de Componentes Principais (PCA). Dois modelos explicativos relacionando a composição da fauna aos fatores ambientais foram construídos: o primeiro 
utilizando apenas variáveis contínuas, e o segundo incluindo as bacias hidrográficas como variável categórica. O Critério de Informação de Akaike (AIC) e o peso do AIC foram utilizados para a seleção do melhor modelo. Apesar de variáveis físicas e físico-químicas terem contribuído significativamente para explicar a composição faunística, o modelo incluindo bacias hidrográficas foi claramente superior (mais de $90 \%$ de suporte nos dados). A importância de bacias de drenagem para a estruturação da comunidade de peixes de riachos pode ter consequências relevantes para o planejamento para a conservação desses ambientes.

Palavras-chave: Ictiofauna, ecologia de peixes, variáveis físicas, variáveis químicas, Amazônia Oriental.

\section{Introduction}

The Neotropical region presents a high diversity of freshwater fish, with nearly 4,500 described species and more than 1,550 species still awaiting scientific description (Reis et al., 2003). The largest drainage basin in the world, covering approximately 7,000,000 $\mathrm{km}^{2}$ (Santos and Ferreira, 1999), is located in the Amazon and is characterized by large rivers and lakes. However, the Amazon also contains countless streams, which constitute one of the largest and densest hydrological networks in the world (Sioli, 1984; Thomas et al., 2004).

Because freshwater fish have limited potential for dispersal in salt water or terrestrial habitats, it is believed that their distribution is strongly associated with historical factors related to the formation of the habitats they occupy (Lundberg, 1993). Some studies have shown that the composition of fish communities is distinct in adjacent basins isolated by watershed divisions (Mendonça et al., 2005; Ingenito and Buckup, 2007). In such cases, the watershed acts as a barrier to the dispersal of species between basins. However, fish community structure is also thought to be influenced by biotic and abiotic factors, which operate and interact on various spatial and temporal scales (Angermeier and Winston, 1998; Matthews, 1998). On a regional scale, physical characteristics, such as stream size (Angermeier and Karr, 1984), water velocity (Mendonça et al., 2005), depth (Angermeier and Karr, 1984; Martin-Smith, 1998), and habitat diversity (Gorman and Karr 1978; Angermeier and Schlosser, 1989), or physico-chemical properties, such as electrical conductivity (Taylor et al., 1993; Mérigoux et al., 1998) and $\mathrm{pH}$ (Townsend et al., 1983), have also been considered to be factors that govern the occurrence and distribution of fish species.

Some studies have found differences in ichthyofauna composition between areas that drain into separate basins, but most studies showing this distinction has been made between large river basins. For example, Matthews and Robison (1988) found significant differences in ichthyofauna composition between basins of major rivers in Arkansas. In New York, Carlson and Daniels (2004) observed significant differences in fish species richness and composition between 19 basins that are part of seven drainage systems in the region. Ingenito and Buckup (2007) reported significant differences in ichthyofauna between the Parnaíba do Sul and Sapucaí basins, but little differentiation within these basins. In the Amazon, Mendonça et al. (2005) found significant differences between streams that drain into the Negro River and those that drain into the Amazon River, but similar ichthyofauna compositions were observed within each of these drainage systems. The authors report physico-chemical differences between the streams, making it difficult to determine whether the basins are acting as discrete units or if physico-chemical characteristics are more relevant in differentiating the ichthyofauna composition.

This study aims to investigate the effects of level 4 basins from the Plano Nacional de Recursos Hídricos (2003) and the structural and physico-chemical variables of the water on fish community structure in streams of the Madeira-Purus interfluve of the Brazilian Amazon. The five water basins included in the study are located in the same geological formation, the Solimões Formation, but one of them drains into the Purus River while the other four drain into the Madeira River. So, they must present some differences on geochemical characteristics, which could reflect in the community structure. However, the ichthyofauna composition can be different between the basins due to the effects of isolation. Thus our aim is to test which are the most influential factors in structuring the ichthyofauna composition in streams of the MadeiraPurus interfluve: the physical and physico-chemical or the isolation represented by drainage basins.

The region under study, the Madeira-Purus interfluve, is one of the most pristine and least-studied regions of the Brazilian Amazon and includes relatively few protected areas. Development policies for the region provided and planned by the Federal Government, such as those related to the opening and paving of roads, waterways, and the building dams and pipelines, underestimate the associated social and environmental impacts on the region (Fearnside and Graça, 2006). Small streams in forest environments are particularly vulnerable to the impacts of human occupation (Dias et al., 2009), and thus, this study also aims to contribute to decision making regarding the conservation of aquatic and terrestrial environments in this region.

\section{Material and Methods}

\subsection{Study area}

The study was conducted in an area around the BR319 highway (which connects Manaus to Porto Velho) in the interfluve of the Madeira and Purus Rivers of the Brazilian Amazon (Figure 1). Two focal areas were selected: one area in the southern part (near Porto Velho, Rondônia State) and another in the northern part of the interfluve (near the city of Manaus, Amazonas State). Two data col- 
lection campaigns were undertaken in April/May and July 2007, and access to sampling locations was limited to the surroundings of the focal areas.

The study area, located on Solimões Formation sediments, has soils predominantly of the red-yellow podzolic type and the climate is equatorial, hot, and humid (Radambrasil, 1978). Average annual temperatures show fluctuations limited by isotherms of $24{ }^{\circ} \mathrm{C}$ and $26{ }^{\circ} \mathrm{C}$. The rainy season usually starts in October, the highest precipitation rates being observed in January, February, and March (Radambrasil, 1978).

\subsection{Basins}

Basins have a hierarchical organization structure, and one difficulty in generalizing its influence on distribution patterns, is to understand at which levels of subdivisions this influence persists. Most studies analyzing the effects of basins on fish composition mention just the names of the major rivers to which sampled streams belong, but other information about the size and location of the basins are not. The hierarchic level considered in this study was the level fourth basins, based on an official classification of Brazilian basins (Plano Nacional de Recursos Hídricos, 2003).

It was not possible to locate springs in advance, and therefore, small bodies of water with relatively closed canopies were sought during sampling site selection. A total of 22 streams were sampled located around the two focal areas, probably of the first to third order, but it was not possible to distinguish these categories a priori. Due to limitations related to the time available for sampling and access to sampling sites, the sampling design was not completely balanced. Based on a map of level fourth basins from the Plano Nacional de Recursos Hídricos (2003), of the 22 streams sampled belonging to five drainage basins (Figure 1), 11 belonged to basin code 4923 (herein referred to as basin 1), which was the only draining into the Purus River, two to 4724 (basin 2), two to 4722 (basin 3), three to 4727 (basin 4), and four to 4726 (basin 5). These four last basins drain into the Madeira River.

\subsection{Data collection}

The sampling procedure employed was based on the protocol developed by Mendonça et al. (2005). In each of the selected streams, a $50 \mathrm{~m}$ stretch was outlined and blocked at both ends using fine mesh nets $(5 \mathrm{~mm}$ between opposing knots) to prevent fish from escaping during collection. Fish were collected only during the day using a $2 \mathrm{~m}$ long sieve ( $2 \mathrm{~mm}$ mesh) and dip nets. Collection effort in each sample was standardized by using three collectors over two hours.

The collected fish were euthanized in clove oil solution (eugenol, two drops per liter) (Canadian Council on
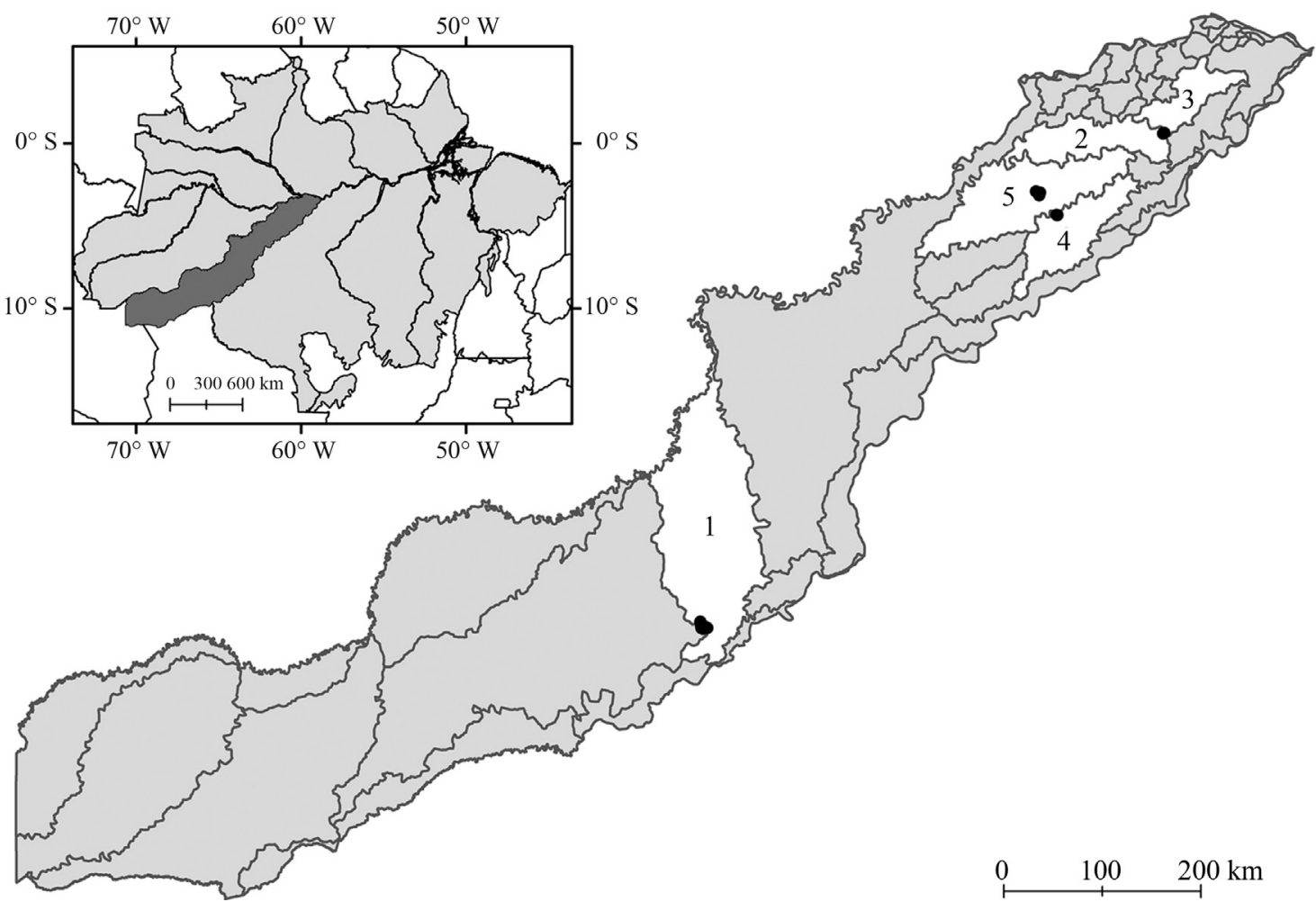

Figure 1 - Map of the basins and sampling site locations in the Madeira-Purus interfluve. The numbers in the figure represent the basins sampled: basin 1, 11 streams sampled; draining into the Purus river; basin 2, two streams; basin 3, two streams; basin, three streams; and basin 5, four streams. Basins 2,3,4, and 5 drain into the Madeira River. 
Animal Care, 2010), then fixed in 10\% formalin. The fish were sorted and identified with the help of experts, and by using dichotomous keys and/or relevant literature. Samples of the collected material were deposited in the Instituto Nacional de Pesquisas da Amazônia (INPA) Fish Collection in Manaus (see Barros et al., 2011). Fish were collected with permission from the Instituto Brasileiro do Meio Ambiente e dos Recursos Naturais Renováveis (IBAMA license \# 10199-1).

For measurement of environmental variables, each $50 \mathrm{~m}$ stretch along the stream from which fish were sampled was divided into four equidistant sections. The following data were gathered from each section: channel width $(\mathrm{m})$, depth $(\mathrm{cm})$, determined from nine equidistant probes along each of the four cross-sections established to measure width), and substrate composition, evaluated in the same points as the depth measurements.

Substrate composition was based on the frequency of occurrence of the following classes: sand, clay, fine litter (fine particulate matter), litter (leaves and twigs), roots (mostly fine, from vegetation on the banks), pebbles, and trunks (wood with a diameter greater than $10 \mathrm{~cm}$ ). Other substrate types were also found, including algae, ferrobacteria, silt, macrophytes, and rocks. However, these substrates showed very low frequencies of occurrence $(\leq 2 \%)$ and were classified as "other" in the analysis.

The velocity of the current $(\mathrm{m} / \mathrm{s})$ was estimated by measuring the time that a loose floating object on the surface of the water took to travel a predetermined distance $(1.0 \mathrm{~m})$ in the center of the channel. Three water velocity measurements were performed along each cross section of the stream. The average flow rate $\left(\mathrm{m}^{3} / \mathrm{s}\right)$ was obtained from the velocity, width, and depth values, as calculated using the following formula: $Q=A^{*} V m$, where: $Q=$ volume; $A=$ average cross-sectional area; and $V m=$ average velocity of the current.

The physical-chemical characteristics of the water were measured at the most downstream point of each section. A portable Aqua-Check ${ }^{\mathrm{TM}}$ Water Analyzer Operator potentiometer/conductivity meter (O.I. Analytical, College Station, TX, USA) was used to measure conductivity $(\mu \mathrm{S} / \mathrm{cm})$ and $\mathrm{pH}$ (potential Hydrogen). Dissolved oxygen $(\mathrm{mg} / \mathrm{l})$ and temperature $\left({ }^{\circ} \mathrm{C}\right)$ were measured using a Model 58 portable Yellow Springs Instruments ${ }^{\mathrm{TM}}$ thermometer (Yellow Springs, OH, USA).

Canopy openness (\%) was estimated based on analysis of four digital photographic images of the forest canopy that were taken above the stream next to each section. Subsequently, the images were imported into ArcView 3.2, transformed into raster files, and the Grid Analyst extension (Saraf, 2000) was used to calculate the proportion of pixels (spots) in the lighted areas (bright spots) and vegetated areas (dark spots). A threshold of $50 \%$ was used to distinguish bright and dark spots. The canopy openness value (\%) was determined by calculating the ratio between the number of bright spots and the total number of spots in the image.

\subsection{Data analysis}

Analysis of the fish community composition was based on values of relative abundance for the species in each stream (dividing the number of individuals of each species by the total at each site). The samples were sorted by Non-Metric Multidimensional Scaling (NMDS) analysis in two dimensions. The association index used was the Bray-Curtis distance. Analysis of the relative species position along the ordination gradient was performed using the average weight of each species along the respective NMDS dimension (Legendre and Legendre, 1998).

To reduce the dimensionality of the structural and physico-chemical characteristics of the streams but maintaining the statistical independence of the variables, environmental variables were summarized by Principal Component Analysis (PCA). Due to the variety of substrates with low representation among the streams, only those that occurred at a frequency greater than $70 \%$ in the samples were included as PCA variables. To perform this analysis, the proportions of each substrate in the samples were arcsine transformed, as recommended by Legendre and Legendre (1998). Based on the number of records of all types of substrates found in each stream, substrate evenness and richness were also calculated and used in the PCA.

Two different models were used to test for the influence of environmental variables and of level 4 basins on the fish communities. The first model intended to test for the effects of environmental variables on fish communities and was a Canonical Correlation Analysis, which included the scores of the first two NMDS dimensions (species composition) as dependent variables and the first three axes of the PCA (environmental variables) as independent variables, generating the model NMDS1, NMDS $2=$ Constant + PCA $1+$ PCA2 + PCA3.

The second model intended to include the effects of drainage basins, which is a categorical variable. As it included both continuous and categorical among the independent variables, it was was a multiple covariance analysis (MANCOVA), which included species composition (also represented by the scores of the first two NMDS dimensions) as a dependent variable, and structural and independent variables were physico-chemical characteristics (continuous, represented by PCA axes), and "drainage basins", as a categorical variable. Because sampling was performed in a relatively small number of streams $(n=22)$, we decided to use the maximum of three environmental variables for inferential analyses. For this reason, we evaluated various combinations of models including drainage basins and PCA. After these evaluations, the model adopted, representing the best combination found, was NMDS1, NMDS2 $=$ Constant + PCA1 + PCA3 + Basins.

Statistical analyses were performed using the Systat 13 program (Systat Software Inc, 2009). Comparison between models and selection of the best model was based on the Akaike Information Criterion (AIC), using a corrected form for small samples (AICc) and relative 
weights of the models (wAIC). According to model selection theory, better models have smaller AIC values and a model can be considered clearly superior when its weight is over 90\% (Burnham and Anderson, 2002).

\section{Results}

We caught 5,508 fish belonging to six orders, 22 families, and 78 species. Characiformes was the most diverse and abundant group, with 39 species, comprising $81.6 \%$ of the collected specimens. The next largest groups in terms of the number of species were Gymnotiformes (15), Siluriformes (12), Perciformes (8), Cyprinodontiformes, and Synbranchiformes (2 species each). Gymnotiformes were the second most abundant group, with $6.3 \%$ of the specimens, followed by Perciformes (4.8\%), Siluriformes (4.2\%), Cyprinodontiformes $(2.7 \%)$, and Synbranchiformes $(0.4 \%)$. Nine species were common to all basins: Apistogramma agassizii (Steindachner, 1875), Carnegiella strigata (Günther, 1864), Erythrinus erythrinus (Bloch and Schneider, 1801), Gymnotus coropinae Hoedeman, 1962, Hoplias malabaricus (Bloch, 1794), Hypopygus lepturus Hoedeman, 1962, Pyrrhulina brevis Steindachner, 1876, Rivulus sp., and Synbranchus sp.

The species composition based on abundance data (NMDS, Stress $=0.17)$ revealed a separation of the streams sampled in basin 1 relative to the other basins along the first dimension (NMDS1; Figure 2A). A trend toward clustering by basin was also evident, with the exception of basin 2, which presented a more heterogeneous dispersion.

Hemigrammus vorderwinkleri Géry, 1963, Hoplerythrinus unitaeniatus (Spix and Agassiz, 1829), Pyrrhulina zigzag Zarske and Géry, 1997, and Rivulus sp. were the main species associated to the smallest val-

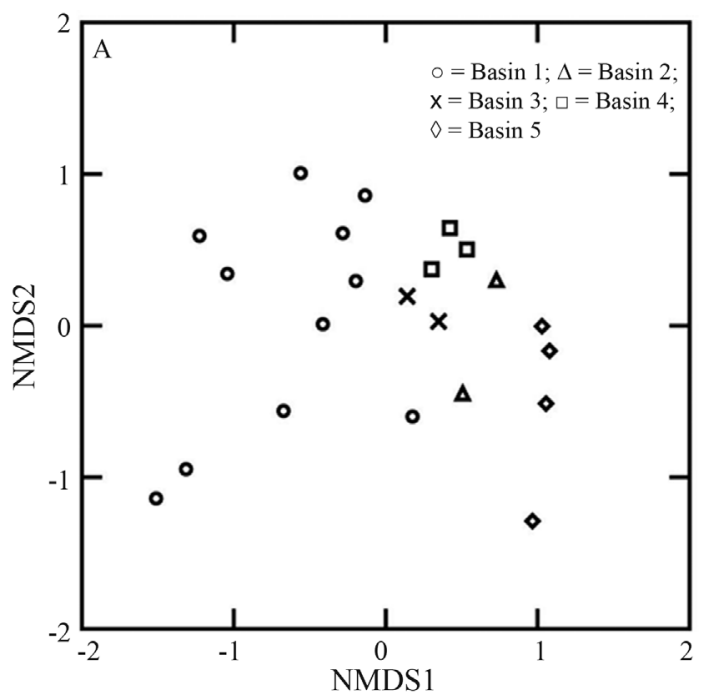

ues along the first ordinate dimension (NMDS1; Figure 3), and help to explain the separation of the streams in basin 1 from the others in two-dimensional space (Figure $2 \mathrm{~A}$ ). The highest values along the first ordinate dimension (NMDS1) were associated with streams of basin 5 (Figure 2A), which is characterized by the presence of Brachyhyроротиs sp.1, Elachocharax junki (Géry, 1971), Microphilypnus ternetzi Myers, 1927, and Physopyxis ananas Sousa and Rapp Py-Daniel, 2005 (Figure 3).

The first three PCA axes explained $63.7 \%$ of the accumulated variance related to structural and physicochemical characteristics of streams (Table 1). Axis 1 (PCA1) explained $30 \%$ of the variance and was strongly and positively related to structural aspects of the channel, such as flow rate, average width, average depth, average maximum depth, and dissolved oxygen (Table 1; Figure 2B). Axis 2 (PCA2) captured 22.2\% of the variance and was primarily related to canopy openness, litter, and trunks (negatively) and to clay and substrate evenness (positively) (Table 1; Figure 2B). Axis 3 explained $11.4 \%$ of the variance and presented a single physical-chemical factor (conductivity) as an important variable (Table 1).

The first model relating species composition to environmental characteristics was statistically significant (Wilks' lambda $=0.32 ; \mathrm{F}=3.18 ; \mathrm{p}=0.008 ; \mathrm{AIC}_{\text {(corrected) }}=$ 117.09). In this model, species composition was significantly related to stream structural characteristics, especially width, depth, and flow rate, which were represented by the first PCA axis (Wilks' lambda $=0.70$; $\mathrm{F}=3.65 ; \mathrm{p}=0.048)$, as well as those represented by the second PCA axis (substrate type and canopy openness, Wilks' lambda $=0.45 ; \mathrm{F}=10.43 ; \mathrm{p}=0.001)$. The third PCA axis showed no significant relationship to species

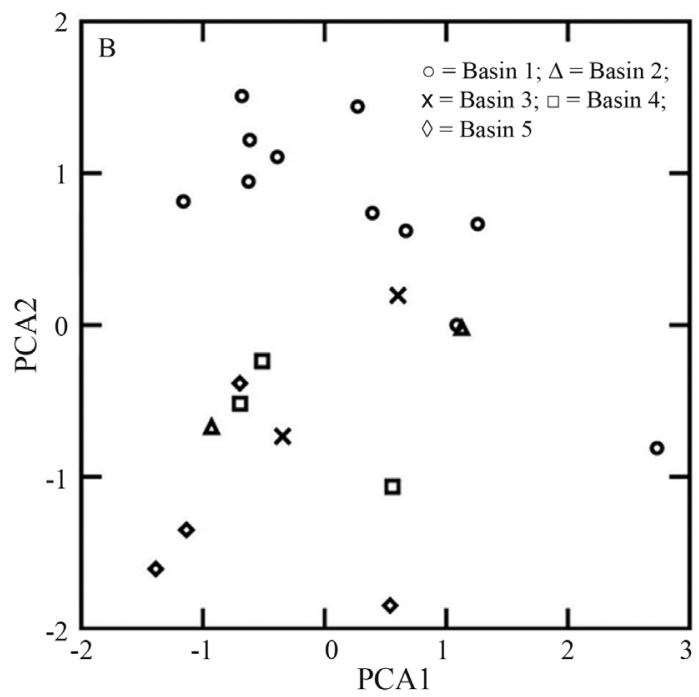

Figure 2 - A) Ordination by Multidimensional Scaling (NMDS) for species abundance data. B) Graphical representation of the first two axes of a Principal Component Analysis performed with measurements of structural and physico-chemical characteristics of the streams sampled. 


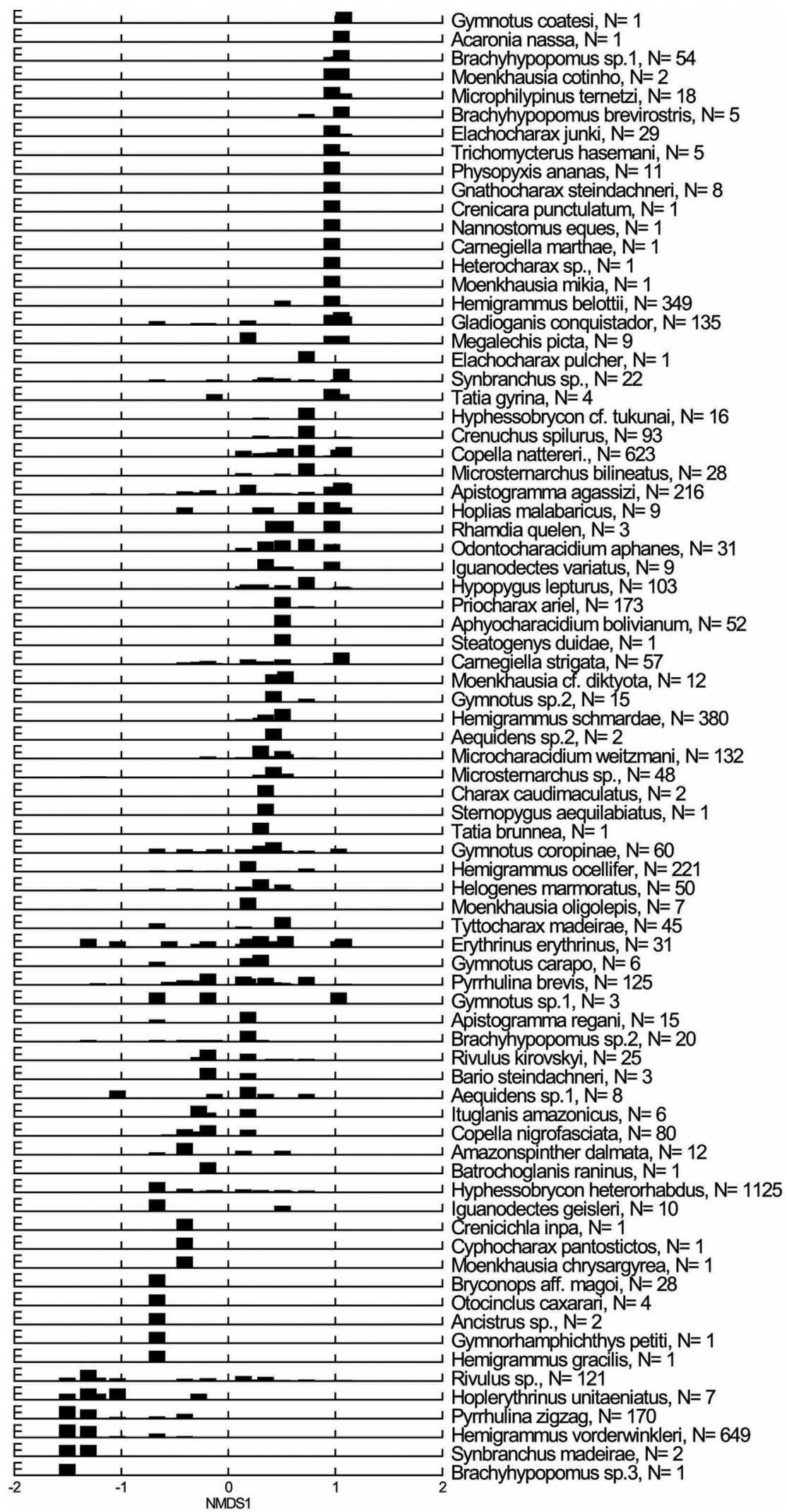

Figure 3 - Direct ordination of fish species along the first dimension of Multidimensional Scaling (NMDS1). N = total number of specimens per species. 
Table 1 - List of environmental variables, including the first three Principal Component Analysis (PCA) axes, their canonical weights ("loadings"), and the explained and cumulative variance percentages.

\begin{tabular}{lccc}
\hline Environmental variables & PCA1 & PCA2 & PCA3 \\
\hline $\mathrm{pH}$ & 0.515 & 0.480 & 0.146 \\
Temperature $\left({ }^{\circ} \mathrm{C}\right)$ & 0.226 & 0.278 & 0.317 \\
Conductivity $(\mu \mathrm{S} / \mathrm{cm})$ & 0.250 & 0.288 & $\mathbf{- 0 . 7 0 9}$ \\
Dissolved oxygen $(\mathrm{mg} / \mathrm{L})$ & $\mathbf{0 . 6 8 7}$ & 0.063 & 0.503 \\
Current velocity $(\mathrm{cm} / \mathrm{s})$ & 0.571 & 0.095 & 0.536 \\
Average width $(\mathrm{m})$ & $\mathbf{0 . 7 4 1}$ & -0.253 & -0.291 \\
Average flow $\left(\mathrm{m}^{3} / \mathrm{s}\right)$ & $\mathbf{0 . 8 3 8}$ & -0.284 & 0.035 \\
Average depth $(\mathrm{m})$ & $\mathbf{0 . 8 6 1}$ & -0.306 & -0.014 \\
Maximum depth $(\mathrm{m})$ & $\mathbf{0 . 8 5 6}$ & -0.321 & 0.008 \\
Canopy openness $(\%)$ & -0.283 & $\mathbf{- 0 . 6 7 8}$ & 0.440 \\
Clay $(\%)$ & 0.021 & $\mathbf{0 . 6 8 5}$ & 0.219 \\
Litter $(\%)$ & -0.289 & $\mathbf{- 0 . 8 7 0}$ & 0.008 \\
Trunks $(\%)$ & 0.465 & $\mathbf{- 0 . 6 5 4}$ & -0.372 \\
Evenness & 0.450 & $\mathbf{0 . 6 4 3}$ & -0.240 \\
Richness & 0.169 & 0.243 & -0.151 \\
\% Explained variance & 30.092 & 22.212 & 11.412 \\
\% Cumulative variance & 30.092 & 52.304 & 63.716 \\
\hline
\end{tabular}

composition (Wilks' lambda $=0.96 ; \mathrm{F}=0.30 ; \mathrm{p}=0.739$ ). The second model was also significant (Wilks' lambda = $\left.0.20 ; \mathrm{F}=5.11 ; \mathrm{p}<0.001 ; \mathrm{AIC}_{\text {(corrected) }}=106.97\right)$. In this model, only the basin variable was significantly related to species composition (Wilks' lambda $=0.28 ; \mathrm{F}=21.49$; $\mathrm{p}=0.000$ ), and none of the tested PCA axes exhibited a significant relationship with species composition (PCA1: Wilks' lambda $=0.82 ; \mathrm{F}=1.86 ; \mathrm{p}=0.186$; PCA3: Wilks' lambda $=0.79 ; \mathrm{F}=2.24 ; \mathrm{p}=0.136)$. Analysis of the relative weights of the different models indicated a weight of $0.6 \%$ for the first model and $99.4 \%$ for the second, clearly indicating that the model including the basins was better.

\section{Discussion}

In the first model applied, the environmental variables that most influenced species composition were stream width, depth, and flow rate. The observed influence of physical variables on species composition is similar to findings obtained in other studies conducted in temperate (Gorman and Karr 1978; Martin-Smith, 1998; Oberdorff et al., 2001) and tropical streams (Angermeier and Schlosser, 1989; Barrella and Petrere Jr., 1994; Araújo-Lima et al., 1999; Uieda and Barretto, 1999; Mendonça et al., 2005) and is in accordance with the river continuum concept (Vannotte et al., 1980), where species abundance and richness increase with enlargement of the stream channel due to greater heterogeneity or increased habitat availability. The observation of phy- sical variation related to the size of the sampled water bodies, although an expected result, is strongly dependent on the selection of streams for sampling. In this study, logistical constraints, related to both movement between areas and sampling time, limited the choice of the streams sampled, leading to large variation in the size of the water bodies sampled within each basin.

The first model also showed that the ichthyofauna was significantly affected by substrate type and canopy openness. The occurrence of several species in streams depends on the characteristics of different habitat types, with the proportions of individual substrate types being an important component (Pires et al., 1999; Humpl and Pivnicka, 2006). In this study, it was found that fish community composition was mainly influenced by the predominance of litter, which was inversely related to the amount of clay. Banks with litter are used by many species of tropical stream fishes as shelter and foraging areas (Henderson and Walker, 1986; Sabino and Zuanon, 1998). Canopy openness is another important habitat component in structuring fish assemblages (Merigoux et al., 1998). High entrance of light decrease protection against solar radiation, causing increases in water temperature and reducing inputs of allochthonous material, which is widely used as food and shelter by aquatic fauna in neotropical stream systems (Sabino and Castro, 1990; Sabino and Zuanon, 1998; Lowe-McConnell, 1999).

In the second model, which included both drainage basins and environmental variables, it was evident that drainage basins had a stronger effect on fish communities than environmental variability. According to the Akaike Information Criterion and the analysis of the relative weights among the models, the second model had a better fit to and greater support from the data than the first, indicating that inclusion of the "drainage basin" categorical variable significantly contributed to understanding factors associated with species composition. It is possible that the inclusion of basins captured some other type of environmental variability that was not measured and analyzed in this study, such as the nutrient concentrations in various streams. However, this type of variation is usually reflected in other physico-chemical variables, such as $\mathrm{pH}$, conductivity, and temperature (Townsend et al., 1983; Taylor et al., 1993; Clenaghan et al., 1998; Mérigoux et al., 1998; Cetra and Petrere Jr., 2006), which were all measured. Thus, although we cannot confirm that the difference in ichthyofauna between basins stems from the effect of historical factors, due to the clear superiority of the model including drainage basins, and differentiation in ichthyiofaunal between contiguous basins, this is the most plausible explanation for the observed differences in species composition between basins.

Basin 1 exhibited the most distinct composition among the basins sampled. This difference may be due to its greater geographical distance from the other basins, considering that long distances between regions are generally associated with less similar fauna (Jackson and Harvey, 1989; Marsh-Matthews and Matthews, 2000). As there was little variability in the distances between all 
the other basins, any analysis involving distances would result in the streams on basin 1 having a high leverage value, potentially leading to spurious results. Besides, stronger differences in basin 1 may have also been due to the fact that this was the only basin that drains into the Purus River (the others drain into the Madeira River), a result in accordance with other studies, which have also found differences in ichthyofauna composition between basins that drain into different large rivers (Matthews and Robison, 1988; Carlson and Daniels, 2004; Mendonça et al., 2005; Ingenito and Buckup, 2007). As basin 1 was different both in terms of distance and drainage direction, and there was no replicates for these differences, it was not possible also to analyze the relative effects of distance and drainage direction on composition, and to assess what of these factors would be responsible for the greater differentiation of the basin 1 .

Fish distribution is usually related to climatic, geomorphological, and historical factors (Roth et al., 1996; Poff and Allan, 1995). According to Hoeinghaus et al. (2007), historical processes, such as speciation and dispersal, strongly affect local communities. In this study, despite the logistical difficulties that prevented better sampling point distribution, the clear superiority of the model including drainage basins supports the idea that isolation is more important than local habitat characteristics for the structuring of fish communities in the Madeira-Purus interfluve. Basins 2-5 were sampled during the same period (drought), exhibit relatively small geographic distances from each other, and all drain into the Madeira River. Despite these similarities, and variation in structural and physico-chemical characteristics among samples within basins, the ichthyofauna composition was different between these basins. These results indicate that smaller drainage basins, at level fourth on the basin classification system, can significantly influence the stream fish community composition. However, to generalize these results and gain more confidence in the representativeness of these findings, additional studies are required at this scale.

Because fish communities in streams are structured along the fluvial continuum and vary between sections with different structural characteristics (Vannote et al., 1989), it is recommended that reserves for conservation of stream fauna include continuous stretches that represent different orders of streams (Abell et al., 2007). Furthermore, considering the differences observed between the drainage basins, it is necessary that streams from the greatest possible number of basins be represented in protected areas, which is a criterion that has not always been included in conservation plans for Amazonian freshwater systems (e.g. Thieme et al., 2007).

\section{Acknowledgments}

We thank the GEOMA project for financial and logistical support in our field and laboratory work. We also thank Mario Cohn-Haft for coordinating the project, PETROBRAS for lending the helicopter that made ac- cess to study areas possible, and IBAMA for providing the license for biological material collection. The first author would like to thank the Instituto Internacional de Educação do Brasil (IIEB) - BECA program, for financial support through a Masters fellowship and the Graduate Program in Environmental Sciences, associated with the UFPA-MPEG-EMBRAPA institutions.

\section{References}

ABELL, R., ALLAN, DJ. and LEHNER, B., 2007. Unlocking the Potential of Protected Areas for Freshwaters'. Biological Conservation, vol. 134, p. 48-63.

ANGERMEIER, PL. and KARR, JR., 1984. Fish communities along environmental gradients in a system of tropical streams. In ZARET, TM. (Ed.). Evolutionary ecology of neotropical freshwater fishes. Netherlands: Dr. W. Junk Publishers. p. 39-57.

ANGERMEIER, PL. and SCHLOSSER, IJ., 1989. Species-area relationship for stream fishes. Ecology, vol. 70, no. 5, p. $1450-1462$.

ANGERMEIER, PL. and WINSTON, MR., 1998. Local vs. Regional influences on local diversity in stream fish communities of Virginia. Ecology, vol. 79, no. 3, p. 911-927.

ARAÚJO-LIMA, CARM., JIMÉNEZ, LF., OLIVEIRA, RS., ETEROVICK, PC., MENDONZA, U. and JEROZOLIMKI, A., 1999. Relação entre o número de espécies de peixes, complexidade de hábitat e ordem do riacho nas cabeceiras de um tributário do rio Urubu, Amazônia Central. Acta Limnologica Brasiliensia, vol. 11, no. 2, p. $127-135$.

BARRELA, W. and PETRERE JR., M., 1994. The influence of environmental factors on fish community structure in Jacaré Pepira River, Brazil. In COWX, IG. (Org.). Rehabilitation of Freshwater Fisheries. Bodman: Fishing News Books. p. 161-170

BARROS, DF., ZUANON, J., MENDONÇA, FP., ESPÍRITOSANTO, HMV., GALUCH, AV. and ALBERNAZ, ALM., 2011. The fish fauna of streams in the Madeira-Purus interfluvial region, Brazilian Amazon. Check List, vol. 7, no. 6, p. 768-773.

BURNHAM, KP. and ANDERSON, DR., 2002. Model selection and multimodel inference: a practical information-theoretic approach. New York: Springer. 488 p.

CANADIAN COUNCIL ON ANIMAL CARE. 2010. CCAC guidelines on: euthanasia of animals used in science. Ottawa. $32 \mathrm{p}$.

CARLSON, DM. and DANIELS, RA., 2004. Status of Fishes in New York: Increases, Declines and Homogenization of Watersheds. The American Midland Naturalist, vol. 152, no. 1, p. 104-139.

CETRA, M. and PETRETE JR, M. 2006. Fish-assemblage structure of the Corumbatai river basin, São Paulo State, Brazil: characterization and anthropogenic disturbances. Brazilian Journal of Biology, vol. 66, no. 2A, p. 431-439.

CLENAGHAN, C., GILLER, PS., O'HALLORAN, J. and HERNAN, R., 1998. Stream macroinvertebrate communities in a conifer-afforested catchment in Ireland: relationships to physico-chemical and biotic factors. Freshwater Biology, vol. 40, no. 1, p. 175-193.

DIAS, MS., MAGNUSSON, WE. and ZUANON, J., 2009. Effects of Reduced-Impact Logging on Fish Assemblages in Central Amazonia. Conservation Biology, vol. 24, no. 1, p. $278-286$. 
FEARNSIDE, PM. and GRAÇA, PMLA., 2006. BR-319: Brazil's Manaus-Porto Velho Highway and the potential impact of linking the arc of deforestation to central Amazonia. Environmental Management, vol. 38, no. 5, p. 705-716.

GORMAN, OT. and KARR, JR., 1978. Habitat structure and stream fish communities. Ecology, vol. 59, no. 3, p. 507 515.

HENDERSON, PA. and WALKER, I., 1986. On the leaf litter community of the Amazonian black water stream Tarumãzinho. Journal of Tropical Ecology, vol. 2, p. 1-17.

HOEINGHAUS, DJ., WINEMILLER, KO. and BIRNBAUM, JS., 2007. Local and regional determinants of stream fish assemblage structure: inferences based on taxonomic vs. functional groups. Journal of Biogeography, vol. 34, no. 2, p. 324-338.

HUMPL, M. and PIVNICKA, K., 2006. Fish assemblages as influenced by environmental factors in streams in protected areas of the Czech Republic. Ecology of Freshwater Fish, vol. 15 , no. 1, p. 96-103.

INGENITO, LFS. and BUCKUP, PA., 2007. The Serra da Mantiqueira, south-eastern Brazil, as a biogeographical barrier for fishes. Journal of Biogeography, vol. 34, no. 7, p. 1173-1182.

JACKSON, DA. and HARVEY, HH., 1989. Biogeographic associations in fish assemblages: local vs. regional processes. Ecology, vol. 70, p. 1472-1484.

LEGENDRE, P. and LEGENDRE, L., 1998. Numerical ecology. Amsterdan: Elsevier. 870 p.

LOWE-MCCONNELL, RH. 1999. Estudos ecológicos de comunidades de peixes tropicais. São Paulo: Editora da Universidade de São Paulo. 534 p.

LUNDBERG, JG. 1993. African-South American freshwater fish clades and continental drift, problems with a paradigm. In GOLDBLATT, P. (Ed.). Biological relationships between Africa and South America. New Haven: Yale University Press. p. 156-198.

MARSH-MATTHEWS, E. and MATTHEWS, WJ., 2000. Geographic, terrestrial and aquatic factors: which most influence the structure of stream fish assemblages in the midwestern United States? Ecology of Freshwater Fish, vol. 9, no. 1-2, p. 9-21.

MARTIN-SMITH, KM., 1998. Relationships between fishes and habitat in rainforest streams in Sabah, Malaysia. Journal of Fish Biology, vol. 52, p. 458-482.

MATHEWS, WJ. and ROBISON, HW., 1988. The distribution of the fishes of Arkansas: a multivariate analysis. Copeia, vol. 2 , p. 358-374

MATTHEWS, WJ., 1998. Patterns in Freshwater Fish Ecology. New York: Chapman and Hall. $756 \mathrm{p}$.

MENDONÇA, FP., MAGNUSSON, WE. and ZUANON, J., 2005. Relationships between habitat characteristics and fish assemblages in small streams of central Amazonia. Copeia, vol. 4, p. 751-764.

MÉRIGOUX, S., PONTON, D. and MÉRONA, B., 1998. Fish richness and species-habitat relationships in two coastal streams of French Guiana, South America. Environmental Biology of Fishes, vol. 51, no. 1, pp. 25-39.

OBERDORFF, T., PONT, D., HUGUENY, B. and CHESSEL, D., 2001. A probabilistic model characterizing riverine fish communities of French rivers: a framework for environmental assessment. Freshwater Biology, vol. 46, p. 399-415.

PLANO NACIONAL DE RECURSOS HÍDRICOS. 2003. Divisão hidrográfica nacional: Ottorbacias do Brasil. Brasília.
PIRES, AM., COWX, IG. and COELHO, MM., 1999. Seasonal changes in fish community structure of intermittent streams in the middle reaches of the Guadiana basin, Portugal. Journal of Fish Biology, vol. 54, p. 235-249.

POFF, NL. and ALLAN, JD., 1995. Functional organization of stream fish assemblages in relation to hydrological variability. Ecology, vol. 76, no. 2, p. 606-627.

RADAMBRASIL. 1978. Mineral, D. N. P. Folha SB. 20 Purus: geologia, geomorfologia, pedologia, vegetação e uso potencial da terra. Rio de Janeiro. $566 \mathrm{p}$.

REIS, RE., KULLANDER, SO. and FERRARIS JR., CJ., 2003. Check list of the freshwater fishes of South and Central America. Porto Alegre: Edipucrs, $742 \mathrm{p}$.

ROTH, NE., ALLAN, JD. and ERICKSON, DL., 1996. Landscape influences on stream biotic integrity assessed at multiple spatial scales. Landscape Ecology, vol. 11, no. 3, p. 141-156.

SABINO, J. and CASTRO, RMC., 1990. Alimentação, período de atividade e distribuição espacial dos peixes de um riacho da floresta Atlântica (sudeste do Brasil). Revista Brasileira de Biologia, vol. 50, no. 1, p. 23-36.

SABINO, J. and ZUANON, J., 1998. A stream fish assemblage in Central Amazônia: distribution, activity pattern and feeding behaviour. Ichthyological Exploration of Freshwaters, vol. 8, no. 3, p. 201-210.

SANTOS, GM. and FERREIRA, JG., 1999. Peixes da bacia Amazônica. In LOWE-MCCONNEL, RH. (Ed.). Estudos ecológicos de comunidades de peixes tropicais. São Paulo: Editora da Universidade de São Paulo. p. 345-373.

SARAF, AK. 2000. Grid analyst extension. India: University of Roorkee.

SIOLI, H. 1984. The Amazon and its main afluents: Hydrography, morphology of the river courses, and river types. In SIOLI, H. (Ed.). The Amazon: limnology and landscape ecology of a mighty tropical river and its basin. Dordrecht: Dr. W. Junk Publishers. p. 127-166.

SYSTAT SOFTWARE, INC. 2009. Systat (Ver. 13).

TAYLOR, CM., WINSTON, MR. and MATTHEWS, WJ., 1993. Fish species-environment and abundance relationships in a Great Plains river system. Ecography, vol. 16, no. 1, p. 16-23.

THIEME, M., LEHNER, B., ABELL, R., HAMILTON, SK., KELLNDORFER, J., POWELL, G. and RIVEROS, JC., 2007. Freshwater conservation planning in data-poor areas: An example from a remote Amazonian basin (Madre de Dios River, Peru and Bolivia). Biological Conservation, vol. 135, p. 500-517.

THOMAS, SM., NEILL, C., DEEGAN, LA., KRUSCHE, AV., BALLESTER, VM. and VICTORIA, RL., 2004. Influences of land use and stream size on particulate and dissolved materials in a small Amazonian stream network. Biogeochemistry, vol. 68, no. 2, p. 135-151.

TOWNSEND, CR., HILDREW, AG. and FRANCIS, J., 1983. Community structure in some southern English streams: the influence of physicochemical factors. Freshwater Biology, vol. 13, p. 521-544.

UIEDA, VS. and BARRETO, MG., 1999. Composição da ictiofauna de quatro trechos de diferentes ordens do rio Capivara, bacia do Tietê, Botucatu, São Paulo. Revista Brasileira de Zoociências, vol. 1, no. 1, p. 55-67.

VANNOTE, RL., MINSHALL, GW., CUMMINS, KW., SENDEL, JR. and CUSHING, CE., 1980. The river continuum concept. Canadian Journal of Fisheries and Aquatic Sciences, vol. 37, p. 130-137. 